\title{
Mesenchymal stem cell-derived exosomes promote hepatic regeneration in drug-induced liver injury models
}

\author{
Cheau Yih Tan ${ }^{1}$, Ruenn Chai Lai ${ }^{3}$, Winnie Wong ${ }^{1}$, Yock Young Dan², Sai-Kiang Lim³ and Han Kiat Ho ${ }^{1 *}$
}

\begin{abstract}
Introduction: Mesenchymal stem cell-conditioned medium (MSC-CM) has been shown to have protective effects against various cellular-injury models. This mechanism of protection, however, has yet to be elucidated. Recently, exosomes were identified as the active component in MSC-CM. The aim of this study is to investigate the effect of MSC-derived exosomes in an established carbon tetrachloride $\left(\mathrm{CCl}_{4}\right)$-induced liver injury mouse model. This potential effect is then validated by using in vitro xenobiotic-induced liver-injury assays: (1) acetaminophen (APAP)- and (2) hydrogen peroxide $\left(\mathrm{H}_{2} \mathrm{O}_{2}\right)$-induced liver injury.
\end{abstract}

Methods: The exosomes were introduced concurrent with $\mathrm{CCl}_{4}$ into a mouse model through different routes of administration. Biochemical analysis was performed based on the blood and liver tissues. Subsequently the exosomes were treated in APAP and $\mathrm{H}_{2} \mathrm{O}_{2}$-toxicants with in vitro models. Cell viability was measured, and biomarkers indicative of regenerative and oxidative biochemical responses were determined to probe the mechanism of any hepatoprotective activity observed.

Results: In contrast to mice treated with phosphate-buffered saline, $\mathrm{CCl}_{4}$ injury in mice was attenuated by concurrent-treatment exosomes, and characterized by an increase in hepatocyte proliferation, as demonstrated with proliferating cell nuclear antigen (PCNA) elevation. Significantly higher cell viability was demonstrated in the exosomes-treated group compared with the non-exosome-treated group in both injury models. The higher survival rate was associated with upregulation of the priming-phase genes during liver regeneration, which subsequently led to higher expression of proliferation proteins (PCNA and cyclin D1) in the exosomes-treated group. Exosomes also inhibited the APAP- and $\mathrm{H}_{2} \mathrm{O}_{2}$-induced hepatocytes apoptosis through upregulation of $\mathrm{BCl}_{-\mathrm{xL}}$ protein expression. However, exosomes do not mitigate hepatocyte injury via modulation of oxidative stress.

Conclusions: In summary, these results suggest that MSC-derived exosomes can elicit hepatoprotective effects against toxicants-induced injury, mainly through activation of proliferative and regenerative responses.

\section{Introduction}

Liver is one of the few organs in the body that possesses an immense capacity to regenerate through the replication of mature functioning liver cells [1]. This protective response is of clinical significance particularly during liver injury. However, when the injury progresses into a state of functional impairment, it can overwhelm or even inhibit the intrinsic regenerative potential, leading to severe consequences that include acute liver failure or

\footnotetext{
* Correspondence: phahohk@nus.edu.sg

'Department of Pharmacy, National University of Singapore, Block S4 18

Science Drive 4, Singapore 117543, Singapore

Full list of author information is available at the end of the article
}

death [2]. Today, xenobiotic (drugs)-induced liver injury accounts for more than $50 \%$ of acute liver failure in the United States and has become a major clinical problem [3]. To overcome this issue, we must explore potential therapeutic agents that can prevent further damage to the injured liver cells. Alternatively, agents that can stimulate remnant liver cells to regenerate could also help to restore liver function in a timely manner and to avert longer-term sequelae.

Mesenchymal stem cell (MSC)-based therapy has been extensively investigated in the area of regenerative medicine for different organs (heart, kidney, lung, and liver) because of its ability to differentiate and transdifferentiate 
into various tissue types (for example, from osteoblasts into adipocytes and chondrocytes) [4], stimulate regeneration, and repair damaged tissue/organs [5]. However, recent reports showed that the bioactive soluble factors found in MSC-conditioned medium (MSC-CM) can stimulate host responses for repair and also reduce the liver-injury level in several different injury models, even without MSC [6-8]. As compared to cell-based therapies, MSC-CM (non-cell-based) therapies are generally preferred because they are less likely to trigger immune response, rendering them safer to use. In addition, they are more amenable to reformulation to support different routes of administration.

Recently, proteomic and computational analysis on the MSC-CM revealed that the secretome in this condition medium (CM) could exert potential modulating effects on tissue repair and regeneration in heart, kidney, and liver [9]. More important, it was demonstrated that the observed cardiac-function preservation was derived from exosomes, a fraction of particle size with $55-100 \mathrm{~nm}$, bilipid membrane secreted microvesicle purified from the MSC-CM [10]. However, it remains to be determined if these size-purified exosomes are able to enrich the hepatoregenerative effect found previously in the conditioned medium, and whether they are efficacious in overcoming liver injury. Furthermore, their ability to respond to different mechanisms of liver injury has not been investigated.

Therefore, this work set out first to explore the potential therapeutic effect in an established $\mathrm{CCl}_{4}$-induced acute liver-injury mouse model followed by characterizing this potential effect by using liver cell-culture models of well-defined xenobiotic-induced liver injury.

\section{Materials and methods Materials and reagents}

Dexamethasone, nicotinamide, gentamicin, HEPES, $\mathrm{NaCl}$, EDTA, glycerine, Triton-X, sodium fluoride, sodium orthovanadate, phenylmethanesulfonyl fluoride (PMSF), aprotinin, 3-(4,5-dimethylthiazol-2-yl)-2,5-diphenyltetrazolium bromide (MTT), acetaminophen (APAP), hydrogen peroxide $\left(\mathrm{H}_{2} \mathrm{O}_{2}\right)$, carbon tetrachloride $\left(\mathrm{CCl}_{4}\right)$, and olive oil were obtained from Sigma Chemical (St. Louis, MO, USA). Dulbecco modified Eagle medium/Ham F12 (DMEM/F12), and Superscript III First-strand Synthesis System are products of Invitrogen (Carlsbad, CA, USA). Insulin, transferrin, and selenium (ITS) is from BD (Franklin Lakes, NJ, USA). Dimethylsulfoxide (DMSO) was obtained from Merck (Darmstadt, Germany). SYBR Green PCR master mix was obtained from Applied Biosystems (Warrington, UK). RNeasy mini kit is a product of Qiagen (Hilden, Germany). Phosphate-buffered saline (PBS) and all primers were synthesized by 1st BASE Oligos (Singapore). Primary antibodies were purchased from the following companies: phospho (Tyr705)-STAT 3, proliferating cell nuclear antigen (PCNA), NF-kB p65, cyclin D and cyclin E, Cell Signaling Technology (Danvers, MA, USA); hepatocyte growth factor (HGF), Abcam (Cambridge, UK). MSC-derived exosomes was prepared and purified as described previously [10].

\section{Animals and diets}

Six-week-old male C57BL/6 mice (21 to $27 \mathrm{~g}$ ) were supplied by the Lab Animals Centre, Singapore. Animals were housed in animal-holding units in National University of Singapore (NUS) at a constant temperature in a 12/12-hour light/dark cycle. All animal procedures were carried out according to a protocol approved by the $\mathrm{Na}$ tional University of Singapore Institutional Animal Care \& Use Committee, Protocol number 123/09. The mice were acclimatized for 2 weeks before use; the mice were 8 weeks of age at the time of experiments. Before the experiment, mice were allowed free access to food and water.

\section{Preparation of MSC-derived exosomes}

The collection of fetal tissue was carried out under a KK Women's and Children's Hospital (KKH) IRB-approved protocol (EC200804062) [11]. Only patients who had already consented to Termination of Pregnancy (TOP) in theKKH Outpatient Clinic were recruited. Recruitment was carried out in strict adherence to KKH IRB regulations to ensure the patient's rights and privacy, and to provide confidential counseling for the patient's fully informed consent to voluntary donation. The patients gave their informed consent for fetal tissue to be collected and used in this study. The hESC-derived HuES9.E1 MSCs were used for the production of MSC secretion in the form of CM, as described [10].

To harvest MSC secretion, $80 \%$ of the confluent HuES9. E1 cultures were washed with PBS, transferred to a chemically defined, serum-free culture medium for an overnight incubation, washed with PBS, and cultured in fresh, chemically defined, serum-free culture medium for 3 days. The CM was collected, clarified by centrifugation, and was concentrated $50 \times$ by tangential flow filtration (TFF) by using a membrane with a $100-\mathrm{kDa}$ MWCO (Sartorius, Goettingen, Germany). CM was fractionated by high-performance liquid chromatography (HPLC) (TSK Guard column SWXL, $6 \times 40 \mathrm{~mm}$ and TSK gel G4000 SWXL, $7.8 \times 300 \mathrm{~mm}$, Tosoh Corp., Tokyo, Japan).

Exosomes were collected from the first peak of the elution and concentrated by using $100 \mathrm{kDa}$ MWCO filter (Sartorius). The identity of the exosomes used in this study had been previously characterized by Lai et al. [10]. Exosomes were filtered with a $0.22-\mu \mathrm{m}$ filter and stored in a $-20^{\circ} \mathrm{C}$ freezer until use. 


\section{$\mathrm{CCl}_{4}$ and exosomes administration}

All mice received a single dose of $\mathrm{CCl}_{4}(3 \% \mathrm{vol} / \mathrm{vol}$ in olive oil) at $0.05 \mathrm{ml} / \mathrm{kg}$ body weight by intraperitoneal injection (i.p.). $0.4 \mu \mathrm{g}(100 \mu \mathrm{l})$ exosomes or $100 \mu \mathrm{l}$ PBS were administered through intrasplenic injection (i.s.) for the treatment group and the vehicle-control group, respectively. All mice were killed 24 hours after $\mathrm{CCl}_{4}$, blood, and livers were collected. The aspartate aminotransferase (AST) and alanine aminotransferase (ALT) activities in the serum were analyzed by using Cobas 4000 analyzer series (Roche, Basel, Switzerland).

\section{Cell lines and culture conditions}

Three different types of hepatocytes were used in the study of cell viability. TAMH, an immortalized mouse hepatocyte line derived from transgenic MT42 male mice overexpressing TGF- $\alpha$ [12], was used as a metabolically competent liver cell line that reproduced features of cytotoxicity to support this investigation, whereas THLE-2 is an immortalized primary human hepatocyte that expresses phenotypic characteristics of normal adult liver epithelial cells [13].

In contrast with the normal cell line, we also investigated the effect of exosomes in $\mathrm{HuH}-7$, a well-differentiated human hepatocarcinoma cell line. This comparison will help to strengthen the evidence of therapeutic effect of exosomes against different liver-injury model in various liver cell types.

Immortalized murine transforming growth factor alpha (TGF- $\alpha$ ) transgenic hepatocyte (TAMH) cells [14] (obtained as a kind gift from Prof Nelson Fausto, University of Washington, Seattle, WA, USA), were maintained in DMEM/F12 supplemented with $5 \mathrm{mg} / \mathrm{ml}$ insulin, $5 \mathrm{mg} / \mathrm{ml}$ transferrin, $5 \mathrm{ng} / \mathrm{ml}$ selenium, $100 \mathrm{n} M$ dexamethasone, 10 $\mathrm{m} M$ nicotinamide, and $0.01 \%$ (vol $/ \mathrm{vol}$ ) gentamicin. $\mathrm{HuH}-7$ obtained from HSRRB (Tokyo, Japan), a human hepatocarcinoma cell line was grown in Dulbecco modified Eagle medium (DMEM) (Sigma) supplemented with 10\% fetal bovine serum (FBS) (Hyclone). THLE-2 obtained from ATCC (Manassas, VA, USA), a human normal liver cell, was cultured in LHC-9 medium supplemented with $10 \%$ FBS (Hyclone). The flasks used were pre-coated with a mixture of $0.01 \mathrm{mg} / \mathrm{ml}$ fibronectin, $0.03 \mathrm{mg} / \mathrm{ml}$ bovine collagen type $\mathrm{I}$, and $0.1 \mathrm{mg} / \mathrm{ml}$ bovine serum albumin (BSA) dissolved in LHC-9 basal medium.

All cells were maintained at $37^{\circ} \mathrm{C}$ in humidified $95 \%$ air and $5 \% \mathrm{CO}_{2}$ atmosphere, passaged and seeded at $80 \%$ to $90 \%$ confluency.

\section{In vitro cell-viability assay}

With 96-well plates, TAMH cells were seeded at a density of $6 \times 10^{3}$ cells/well in $200 \mu \mathrm{l}$ DMEM/F12 medium, whereas THLE- 2 cells were seeded at a density of $1 \times 10^{4}$ cells/well in $200 \mu \mathrm{l} \mathrm{LHC-9}$ medium overnight. HuH-7 cells were seeded at a density of $5 \times 10^{3}$ cells/well for 72 - hour treatment, and $7.5 \times 10^{3}$ cells/well for 24-hour treatment in $200 \mu \mathrm{l}$ DMEM medium overnight. TAMH, HuH-7, and THLE- 2 cells were treated with various concentrations of exosomes in their respective culturing medium for 24 or 72 hours. Cell-viability assays were performed after the respective incubation time to determine the cytotoxicity of exosomes. In TAMH cells, $2 \mathrm{~m} M$ APAP or 350 $\mu M \mathrm{H}_{2} \mathrm{O}_{2}$ was treated in the TAMH cells concurrent with $0.05 \mu \mathrm{g} / \mathrm{ml}$ or $0.1 \mu \mathrm{g} / \mathrm{ml}$ of exosomes for 24 hours before performing the cell-viability test. HuH-7 and THLE-2 cells were treated with $5 \mathrm{~m} M$ and $3.5 \mathrm{~m} M$ APAP, respectively, with $0.05 \mu \mathrm{g} / \mathrm{ml}$ or $0.1 \mu \mathrm{g} / \mathrm{ml}$ of exosomes for 72 hours before performing the cell-viability test.

PBS was used as background for exosomes treated in the control groups. After incubation of toxicants with different concentrations of exosomes, the cell viability was evaluated with MTT assay. Then $20 \mathrm{ml}$ of $5 \mathrm{mg} / \mathrm{ml}$ MTT was dissolved in PBS. After the incubation period, the media was aspirated, and the formazan crystals in cells were dissolved in $200 \mu \mathrm{l}$ of DMSO and $25 \mu \mathrm{l}$ of Sorenson buffer [15]. The absorbance was read at $570 \mathrm{~nm}$ by using a Tecan microtiter plate reader. Cell-viability percentage was expressed as a ratio of cells exposed to different concentrations of toxicants with those of vehicle controls.

\section{Reverse transcription and quantitative real-time polymerase chain reaction}

In a six-well plate, TAMH cells were seeded at a density of $0.5 \times 10^{6}$ cells/well and treated with $2 \mathrm{~m} M$ APAP or $350 \mu M$ $\mathrm{H}_{2} \mathrm{O}_{2}$ concurrent with $0.05 \mathrm{mg} / \mathrm{ml}$ or $0.1 \mathrm{mg} / \mathrm{ml}$ of exosomes for 24 hours. All cells were harvested for total cell RNA extraction by using RNeasy columns (Qiagen, Valencia, CA, USA). The quality and quantity of total RNA was determined with NanoDrop (Thermo, Wilmington, DE, USA), ensuring that RNAs with OD 260/280>1.80 were used. First-strand cDNA was synthesized from $1 \mu \mathrm{g}$ total RNA by using Superscript First-Strand Synthesis System, according to the protocols of the manufacturer. qRT-PCR was performed by using BioRad CFX96 real-time PCR system with SYBR Green master mix and primers, as shown in Table 1. The thermal-cycling condition comprised an initial denaturation at $95^{\circ} \mathrm{C}$ (10 minutes), followed by 40 cycles at $95^{\circ} \mathrm{C}(15 \mathrm{sec}-$ onds) and $60^{\circ} \mathrm{C}$ (60 seconds). Melting curves were generated at the end of 40 cycles to verify the purity of the PCR product. Data were obtained as average Ct values, and normalized against the geometric mean of GAPDH endogenous controls as $\mathrm{Ct}$. Transcript differences between the exosomes-treated group and the nontreated group were measured as fold changes by using the comparative $\mathrm{Ct}$ method. Statistics were performed on Ct by using REST software (Qiagen).

\section{Western blots}

Mouse liver tissue was homogenized by using glass dounce homogenizer. Proteins were lysated with $800 \mu$ of lysis 
Table 1 Sequences of primers used in real-time PCR reaction

\begin{tabular}{|c|c|c|}
\hline Gene & Forward primer $\left(5^{\prime}->3^{\prime}\right)$ & Reverse primer $\left(5^{\prime}->3^{\prime}\right)$ \\
\hline \multicolumn{3}{|c|}{ In vitro hepatocytes (TAMH cells)/In vivo liver (mouse) } \\
\hline TNF-a & ATG AGC ACA GAA AGC ATG ATC & TAC AGG CTT GTA ACT CGA ATT \\
\hline $\mathbb{I L}-6$ & AGT TGC CTT CTT GGG ACT GA & TCC ACG ATT TCC CAG AGA AC \\
\hline iNOS & CAC CTT GGA GTT CAC CCA GT & ACC ACT CGT ACT TGG GAT GC \\
\hline $\operatorname{cox}-2$ & CTC CCT GAA GCC GTA CAC AT & GCT CGG CTT CCAA GTA TTG AG \\
\hline MIP-2 & AAG TIT GCC TTG ACC CTG AA & AGG CAC ATC AGG TAC GAT CC \\
\hline $\mathrm{HO}-1$ & CAG GTG ATG CTG ACA GAG GA & ATG GCA TAA ATT CCC ACT GC \\
\hline Gpx4 & CCG GCT ACA ACG TCA AGT TT & CGG CAG GTC CTT CTC TAT CA \\
\hline Gsr & ACC ACG AGG AAG ACG AAA TG & GGT GAC CAG CTC CTC TGA AG \\
\hline MnSOD & GGC CAA GGG AGA TGT TAC AA & CCT TGG ACT CCC ACA GAC AT \\
\hline GAPDH & GGC ATT GCT CTC AAT GGAC AA & CCG AGGT TGG GAT AGG GCC \\
\hline
\end{tabular}

buffer containing $50 \mathrm{~m} M$ HEPES pH 7.5, $150 \mathrm{~m} M \mathrm{NaCl}, 1$ $\mathrm{m} M$ EDTA, $10 \%$ glycerine, $1 \%$ triton-X, $0.5 M$ sodium fluoride, $100 \mathrm{~m} M$ sodium orthovanadate, $100 \mathrm{mM}$ PMSF, and $20 \mathrm{mg} / \mathrm{ml}$ aprotinin. TAMH cells were seeded at $2 \times$ $10^{6}$ in a $10-\mathrm{cm}$ dish with DMEM/F12 medium overnight. The medium was changed to DMEM/F12 low glucose and cultured for 2 days. Cells were then treated with respective concentrations of APAP or $\mathrm{H}_{2} \mathrm{O}_{2}$ and exosomes for 24 hours. All cells were harvested for Western blot analysis. Cell pellets were lysed with $100 \mu \mathrm{l}$ of RIPA lysis buffer containing $50 \mathrm{~m} M$ Tris, $150 \mathrm{~m} M \mathrm{NaCl}, 0.1 \%$ SDS, $0.5 \%$ sodium deoxycholate, 1\% NP-40, $0.5 \mathrm{M}$ sodium fluoride, $100 \mathrm{~m} M$ sodium orthovanadate, $100 \mathrm{~m} M$ PMSF, and $20 \mathrm{mg} / \mathrm{ml}$ aprotinin. The $40 \mathrm{mg}$ total protein per mouse sample and $10 \mu \mathrm{g}$ per cell sample were resolved in $10 \%$ SDS-PAGE and immobilized on PVDF membrane. The membranes were blocked in 5\% milk for 1 hour and incubated in respective primary antibodies overnight (pSTAT3, 1:1,000; NF-kB, 1:2,000; Bcl- $_{x L}$ 1:1,000; PCNA, 1:10,000; and cyclin D1, 1:1,000), followed by respective secondary antibody $(1: 10,000)$ incubation for 1 hour. All membranes were visualized by using chemiluminescence substrate (Pierce Biotechnology, Rockford, IL, USA). The band intensities were normalized against actin and were quantified by using ImageJ software.

\section{Statistical analysis}

Data were expressed as means \pm standard error of means (SEM) and analyzed by using Student two-tailed $t$ test. Statistical significance of the difference was accepted at $P$-values of less than 0.05 .

\section{Results}

Exosomes reduced liver-injury level in ALT and AST after $\mathrm{CCl}_{4}$ treatment in vivo

A preliminary experiment revealed that serum AST and ALT gradually increased and peaked at 24 hours after a single dose of $\mathrm{CCl}_{4}$ (data not shown). Thus, AST and
ALT were measured at 24 hours after respective treatments. Mice receiving $0.05 \mathrm{ml} / \mathrm{kg} \mathrm{CCl}_{4}$ demonstrated significant increases in AST and ALT within 24 hours of dosing. In mice treated with $\mathrm{CCl}_{4}$ and exosomes, the increase of AST and ALT after 24 hours was significantly less than the PBS-treatment group (Figure 1A). Histologically, the hematoxylin and eosin (H\&E) staining of liver tissues for the $\mathrm{CCl}_{4}$ group showed moderate hepatic necrosis, whereas minimal necrotic cells were observed in the exosomes treatment group (Figure 1B).

\section{Exosomes induced hepatocyte-regenerative genes expression in liver tissue after $\mathrm{CCl}_{4}$-induced injury}

To investigate the regenerative effect of exosomes, few of the transcription factors and growth factors expression involved in different stages of the cell cycle were examined by using immunoblot assays on the liver tissue. As can be seen from Figure 2A, the exosomes treatment group showed significant upregulation of the hepatic gene expressions of NF-kB, cyclin D1, and cyclin $\mathrm{E}$ in contrast with the untreated. No significant upregulation was observed for HGF and p-STAT3 gene expression. The activation of proliferation was also demonstrated by the higher number of $\mathrm{PCNA}^{+}$-stained cells in the exosomes treatment group (Figure $2 \mathrm{C}$ ) as compared with the PBS-treatment group (Figure 2B).

\section{Exosomes exerted no intrinsic cytotoxicity while} demonstrating increased cell viability in TAMH, THLE-2, and Huh-7 hepatocytes after APAP- or $\mathrm{H}_{2} \mathrm{O}_{2}$-induced injuries

In vitro models were subsequently designed to validate the in vivo findings of exosomal protection and to gain further insights into its response toward different mechanisms of toxicity; APAP represents the liver-injury model caused by both covalent modification of protein targets and oxidative stress-mediated injury pathways [16], whereas $\mathrm{H}_{2} \mathrm{O}_{2}$ represents only the oxidative stressinduced liver-injury pathway. Three representative liver 

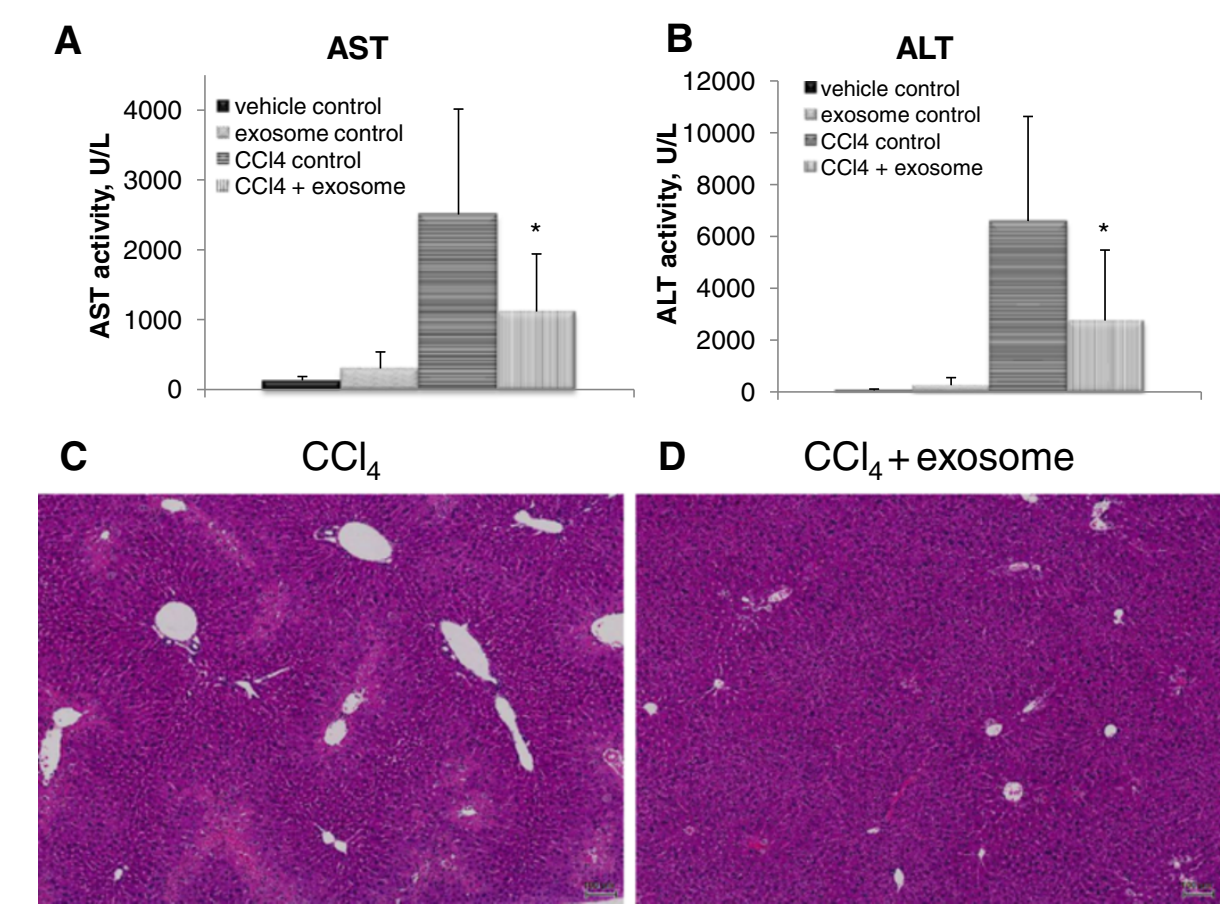

Figure 1 Effect of exosomes on biochemical parameters and hepatocyte injury after $\mathrm{CCl}_{4}$ treatment in vivo. Serum (A) aspartate aminotransferase (AST) and (B) alanine aminotransferase (ALT) levels were measured after 24-hour dosing of $\mathrm{CCl}_{4}$ with or without exosomes administration ( $n=6$ per group; ${ }^{*} P<0.05$ versus of $\mathrm{CCl}_{4}$ control for both AST and ALT). Standard hematoxylin and eosin (H\&E) staining for liver tissue harvested after 24 hours of (C) $\mathrm{CCl}_{4}$ administration and (D) $\mathrm{CCl}_{4}$ with exosomes treatment. Obvious hepatic necrosis appeared in the section from a $\mathrm{CCl}_{4}$-treated animal. Original magnification $\times 80$; scale bar, $100 \mu \mathrm{m}$.

cell lines, TAMH, THLE-2, and HuH-7 cells, were subjected to these xenobiotic-induced injuries. The exosomes concentration used in this study was $0.1 \mu \mathrm{g} / \mathrm{ml}$. This concentration was chosen as it had demonstrated cardioprotection in a previous study [10]. Further in our current evaluation, this concentration did not display any cytotoxicity across the three cell lines (Figure 3A,D, G). Cytoprotection against APAP- and $\mathrm{H}_{2} \mathrm{O}_{2}$-induced liver injury in TAMH cells was clearly demonstrated (Figure 3B,C). The same concentration of exosomes seemed to demonstrate better protection against APAP injury as compared with the $\mathrm{H}_{2} \mathrm{O}_{2}$-injury model. When cross-referenced and confirmed with THLE-2 and $\mathrm{HuH}-$ 7, comparable results were observed. Treatment of 0.1 $\mu \mathrm{g} / \mathrm{ml}$ exosomes demonstrated significantly higher cell viability in both toxicant-induced liver-injury models by using THLE-2 (Figure 3D-F) and HuH-7 when compared with untreated cells (Figure 3G-I).

\section{Exosomes regulated hepatocytes proliferation through} inducing quiescent hepatocytes $\left(\mathrm{G}_{0}\right)$ to re-enter the cell cycle $\left(\mathrm{G}_{1}\right)$ at the priming phase after APAP- or $\mathrm{H}_{2} \mathrm{O}_{2}$-induced injury By determining the modulation of early priming cytokines expression, an exosomal mechanism of cytoprotection could be elucidated. Hence, cell growth was first arrested by culturing in low-glucose DMEM/F12 medium for 2 days. Then, treatment with APAP or $\mathrm{H}_{2} \mathrm{O}_{2}$ was introduced, either with or without MSC exosomes. Finally, geneexpression levels of the priming factors were measured after 24 hours of these treatments. As shown in Figure 4A and $\mathrm{B}, 0.1 \mu \mathrm{g} / \mathrm{ml}$ of exosomes-treated group was observed to have elevated mRNA expressions of tumor necrosis factor alpha (TNF- $\alpha$ ), interleukin 6 (IL-6), inducible nitric oxide synthase (iNOS), cyclooxygenase-2 (COX-2), and macrophage inflammatory protein 2 (MIP-2), as compared with the untreated group.

In the APAP-injury model, MIP-2 demonstrated the highest elevation with 3.7 -fold, followed by 2.4 -fold in COX-2 and twofold in iNOS. The elevation trend differed slightly in the $\mathrm{H}_{2} \mathrm{O}_{2}$-injury model, whereby the same amount of exosomes was found to increase iNOS expression the most significantly, by approximately 2.9 -fold, followed by twofold increase in all three MIP-2, COX-2, and $I L-6$ genes compared with the non-exosomes-treated group (Figure 4B).

\section{Exosomes induced transcription factors expression during} the $\mathrm{G}_{1}$ phase of cell cycle after APAP- or $\mathrm{H}_{2} \mathrm{O}_{2}$-induced injury Based on the observed elevation of TNF- $\alpha$ and IL- 6 with exosomal treatment, the downstream effect of NF-kB and STAT3 transcription factors activation in the $G_{1}$ phase of the cell cycle was explored. These activations 


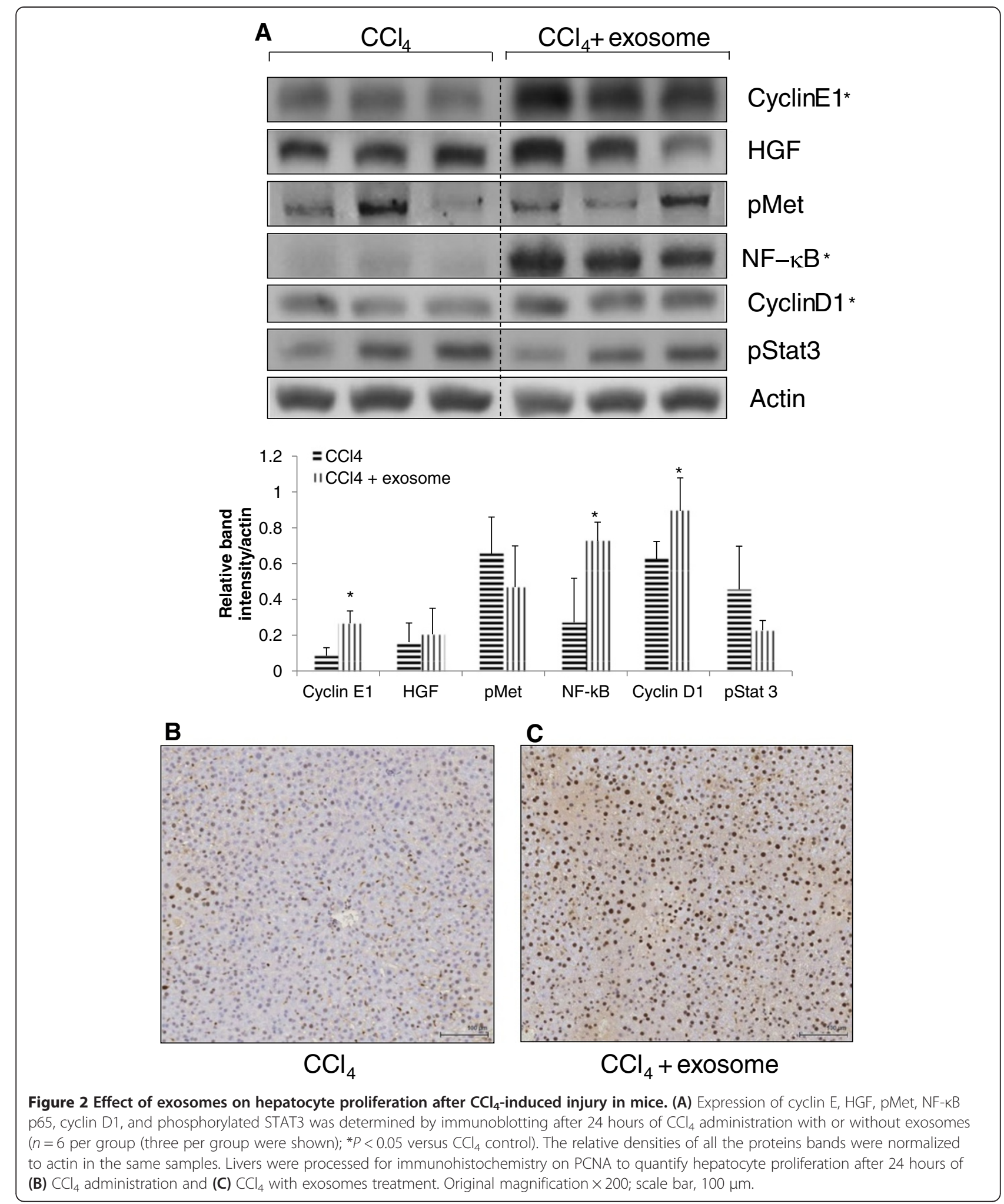

support the propagation of proliferative signals during liver regeneration [17]. The activation of these factors was investigated by immunoblotting of NF-kB (p65 and p50) and phospho-STAT3 (TYR705) after treatment of exosomes in both xenobiotic-induced hepatocyteinjury models. Without exosomes treatment, APAP- and $\mathrm{H}_{2} \mathrm{O}_{2}$-treated cells exhibited low basal levels of NF- $\mathrm{kB}$ and phospho-STAT3 activity (Figure 5, lane 2 and 5, 


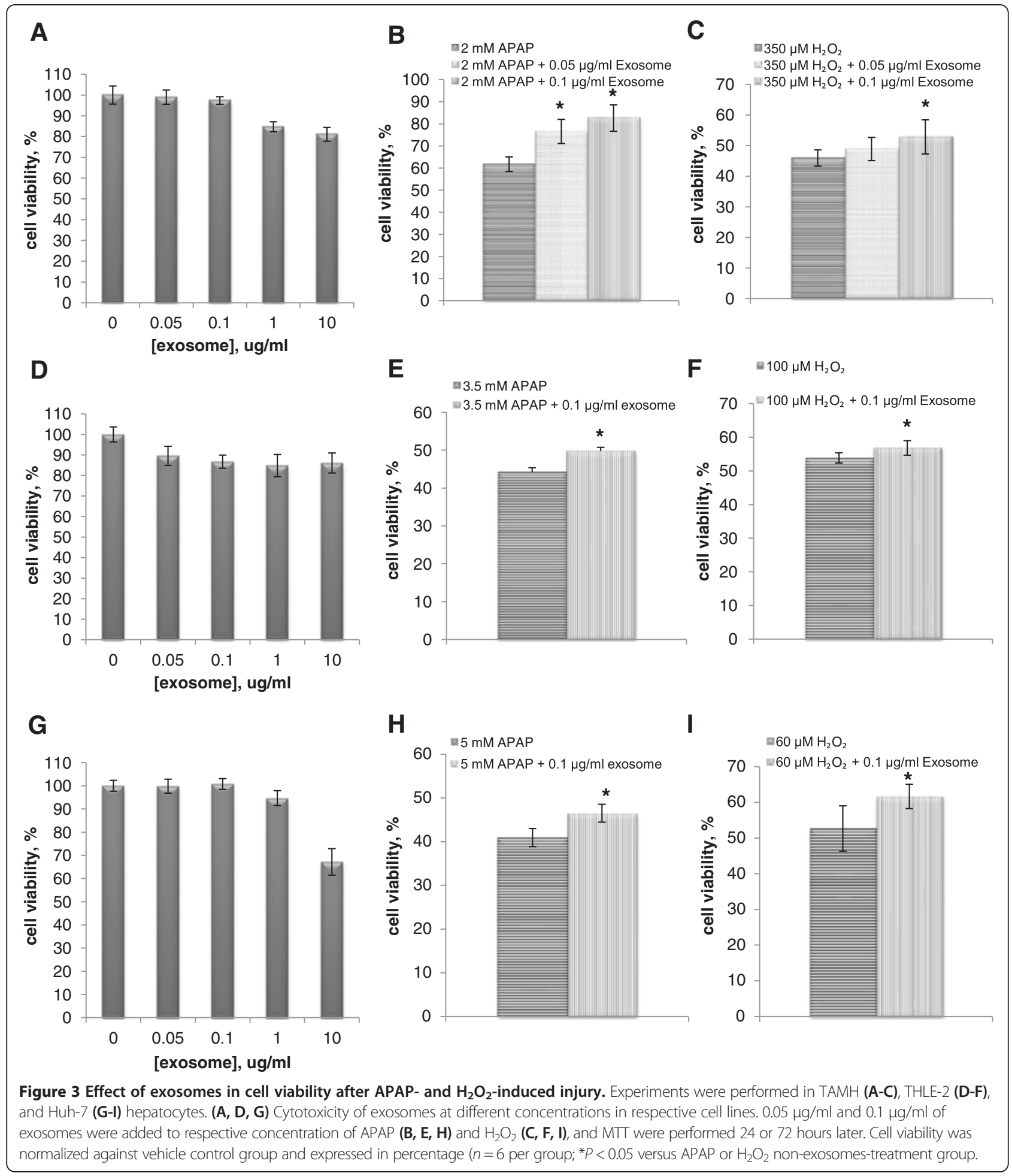

respectively). With exosomal treatment, NF- $\mathrm{B}$ (both p50 and p65) and phospho-STAT3 activities were restored to the normal expression levels in APAP-induced injury (Figure 5, lanes 3 and 4). Interestingly, higher levels of induction of the two proteins were more prominent in the $\mathrm{H}_{2} \mathrm{O}_{2}$-treated cells (Figure 3, lanes 6 and 7).
Exosomes upregulated the expression of cell-proliferation markers (at $\mathrm{G}_{1}$ and $\mathrm{S}$ phase) after APAP- or $\mathrm{H}_{2} \mathrm{O}_{2}$-induced injury

After the observed restoration of NF-kB and STAT3 signaling with exosomal treatment, we pursued the search for biochemical evidence of active cell cycling by monitoring 

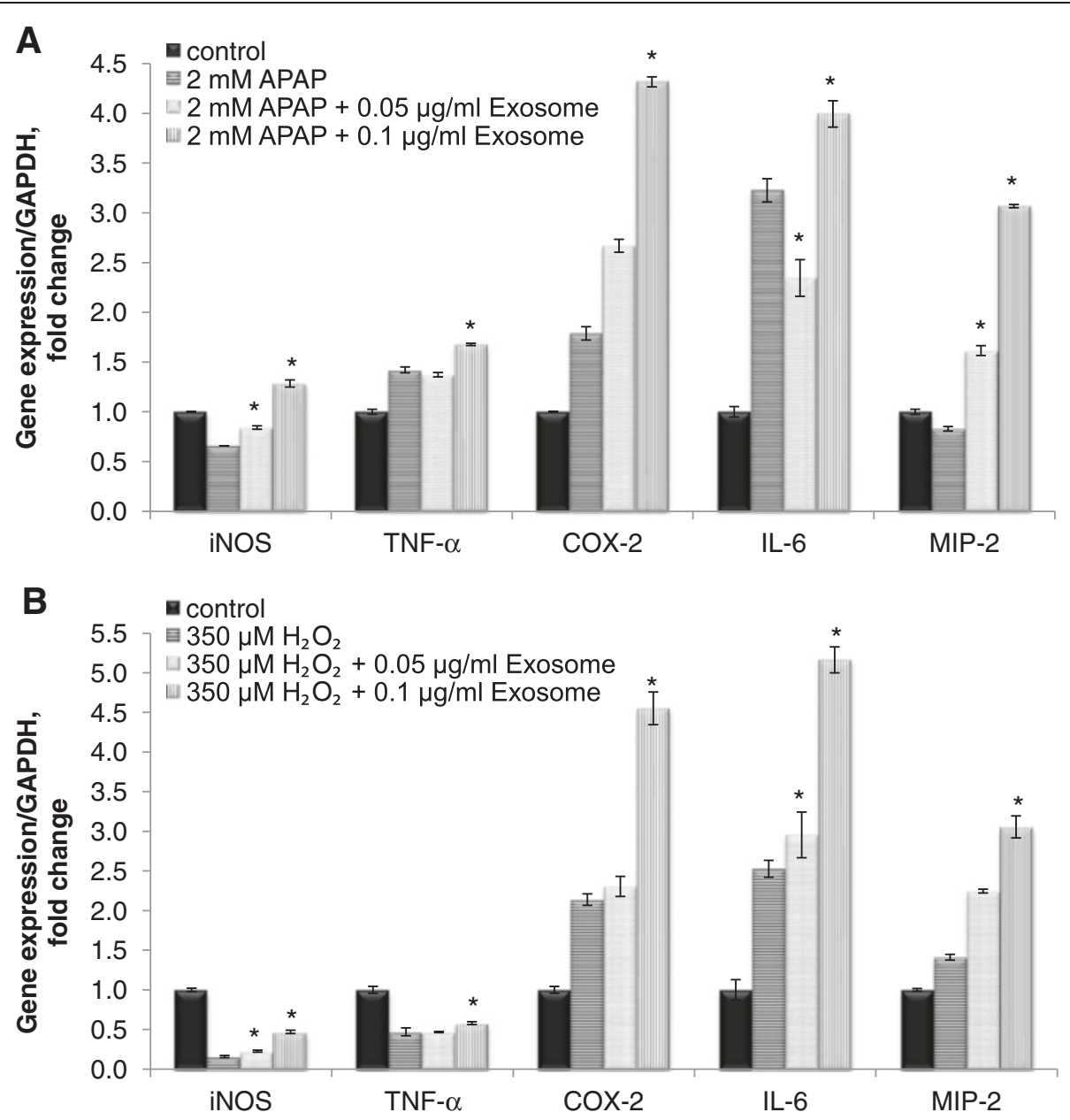

Figure 4 Effect of exosomes in hepatoregenerative-expression genes on APAP- and $\mathrm{H}_{2} \mathrm{O}_{2}$-induced injury in hepatocytes. Expression of regenerative-response genes after 24 hours of exosomes in (A) APAP and (B) $\mathrm{H}_{2} \mathrm{O}_{2}$ treatment was determined by quantitative real-time PCR and normalized against GAPDH expression of the same sample and presented as fold-increase over the controls. Bars represent means \pm SEM. ${ }^{*} P<0.05$ versus APAP or $\mathrm{H}_{2} \mathrm{O}_{2}$ nonexosomes treatment group.

cyclin D1 and PCNA. Exosomes treatment increased the expression of cyclin D1 and PCNA in a dose-dependent manner during APAP and $\mathrm{H}_{2} \mathrm{O}_{2}$ injury (Figure 6). This finding is consistent with our earlier results, which demonstrated that MSC-derived exosomes promoted hepatocyte regeneration and proliferation during acute injury.

\section{Exosomes protected hepatocytes from apoptosis by decreasing caspase $3 / 7$ level while upregulating antiapoptotic gene $B \mathrm{Cl}_{-x L}$}

Besides being a mitogenic transducer, STAT3 is also indicative of early response toward promotion of antiapoptotic activity. STAT3 could also suppress Fas-mediated liver injury either by a redox-dependent mechanism through expressing antiapoptotic genes such as $\mathrm{Bcl}_{-\mathrm{xL}}$, $\mathrm{Bcl}-2$ [18], or by a redox-independent mechanism through expressing Ref-1 [19] or anti-oxidative gene, manganese superoxide dismutase (MnSOD) [20]. To further determine if the anti- apoptotic effect was due to the upregulation of p-STAT3, caspase 3/7 activities were measured in this study. Both toxicant-only treatments resulted in significant increment of active caspase 3 and reduction of antiapoptotic gene, $\mathrm{Bcl}_{-\mathrm{xL}}$, as compared with the control (Figure 7A,B). Similar to the favorable outcomes in cell viability, in APAP-injury model, exosomes treatment significantly suppressed the activity of caspase 3 . This suppression was not observed in the $\mathrm{H}_{2} \mathrm{O}_{2}$-injury model. As for $\mathrm{Bcl}_{-\mathrm{xL}}$, treatment of exosomes seemed to reverse the suppression observed in toxicant-only treatment. With higher exosomes concentrations, further increase in expression was demonstrated in both APAP- and $\mathrm{H}_{2} \mathrm{O}_{2}$ - induced injury models (Figure 7B, lanes 4 and 7).

\section{Exosomes did not regulate the antiapoptotic effect} through antioxidative genes

Further to assess the antiapoptotic effect of exosomes mediated through the antioxidative pathway, mRNA expression 


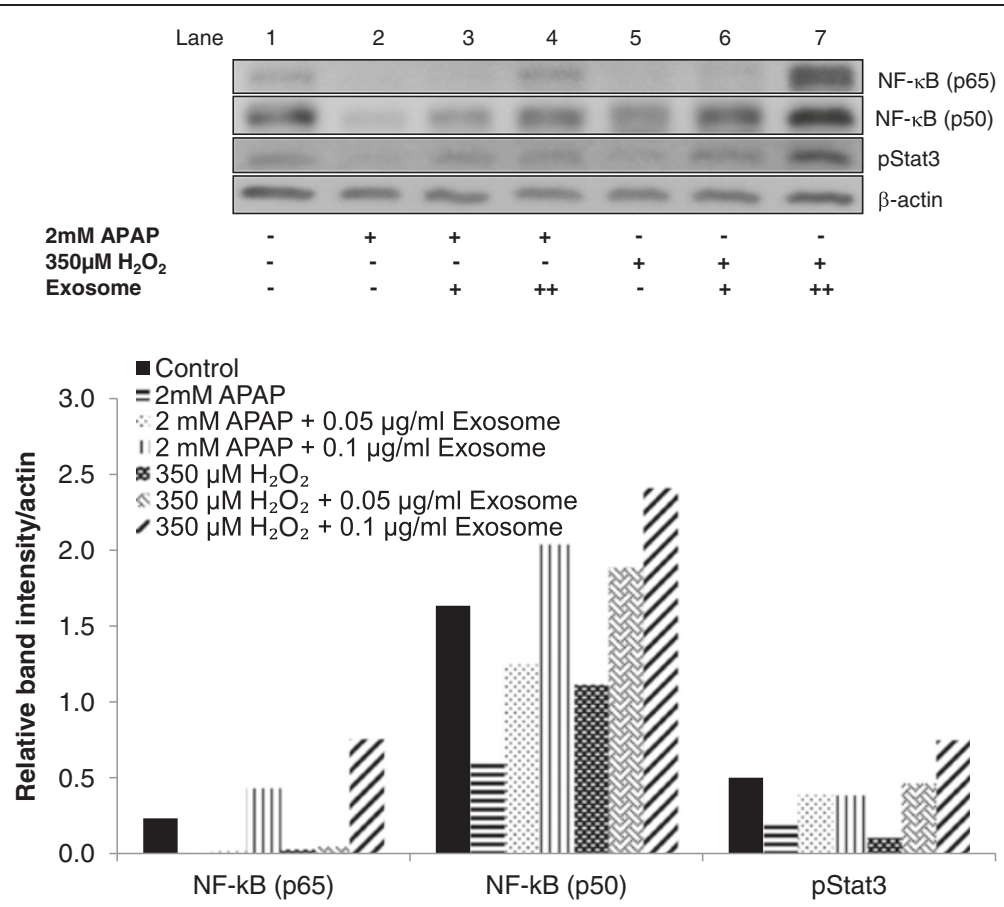

Figure 5 Effect of exosomes in $\mathrm{G}_{1}$ phase of the cell cycle after APAP- or $\mathrm{H}_{2} \mathrm{O}_{2}$-induced injury in hepatocytes. Expression of NF- $\mathrm{kB}$ (p65 and p50) and phosphorylated STAT3 was determined by immunoblotting after 24-hour treatment in APAP- or $\mathrm{H}_{2} \mathrm{O}_{2}$-injury models. The relative densities of NF-KB and phosphorylated STAT3 bands were normalized to actin in the same samples.

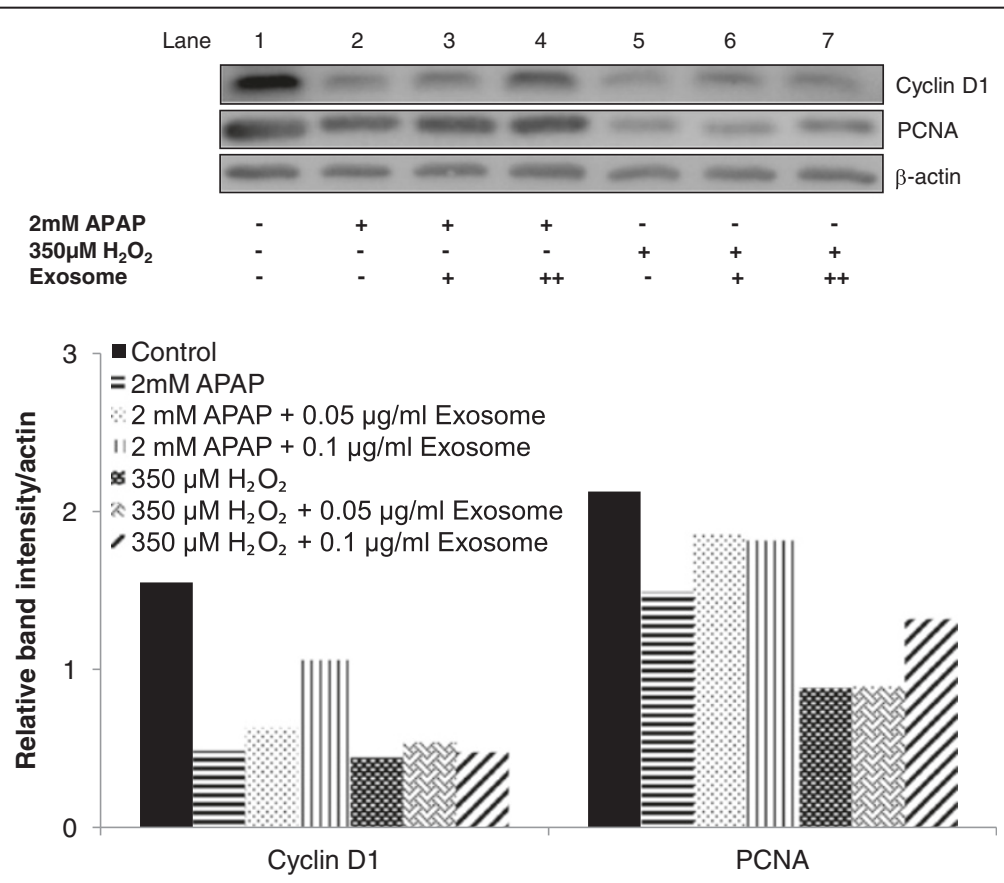

Figure 6 Effect of exosomes in cell proliferation after APAP- or $\mathrm{H}_{2} \mathrm{O}_{2}$-induced injury in hepatocytes. Expression of cyclin D1 and PCNA was determined by immunoblotting after 24-hour treatment in the APAP- or $\mathrm{H}_{2} \mathrm{O}_{2}$-injury model. The relative densities of cyclin D1 and PCNA bands were normalized to actin in the same samples. 


\section{A}

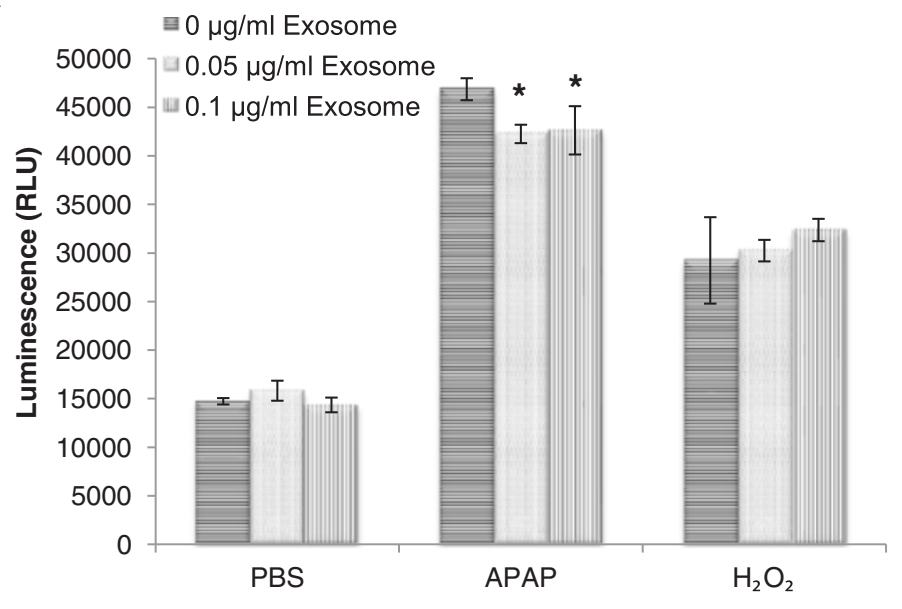

B
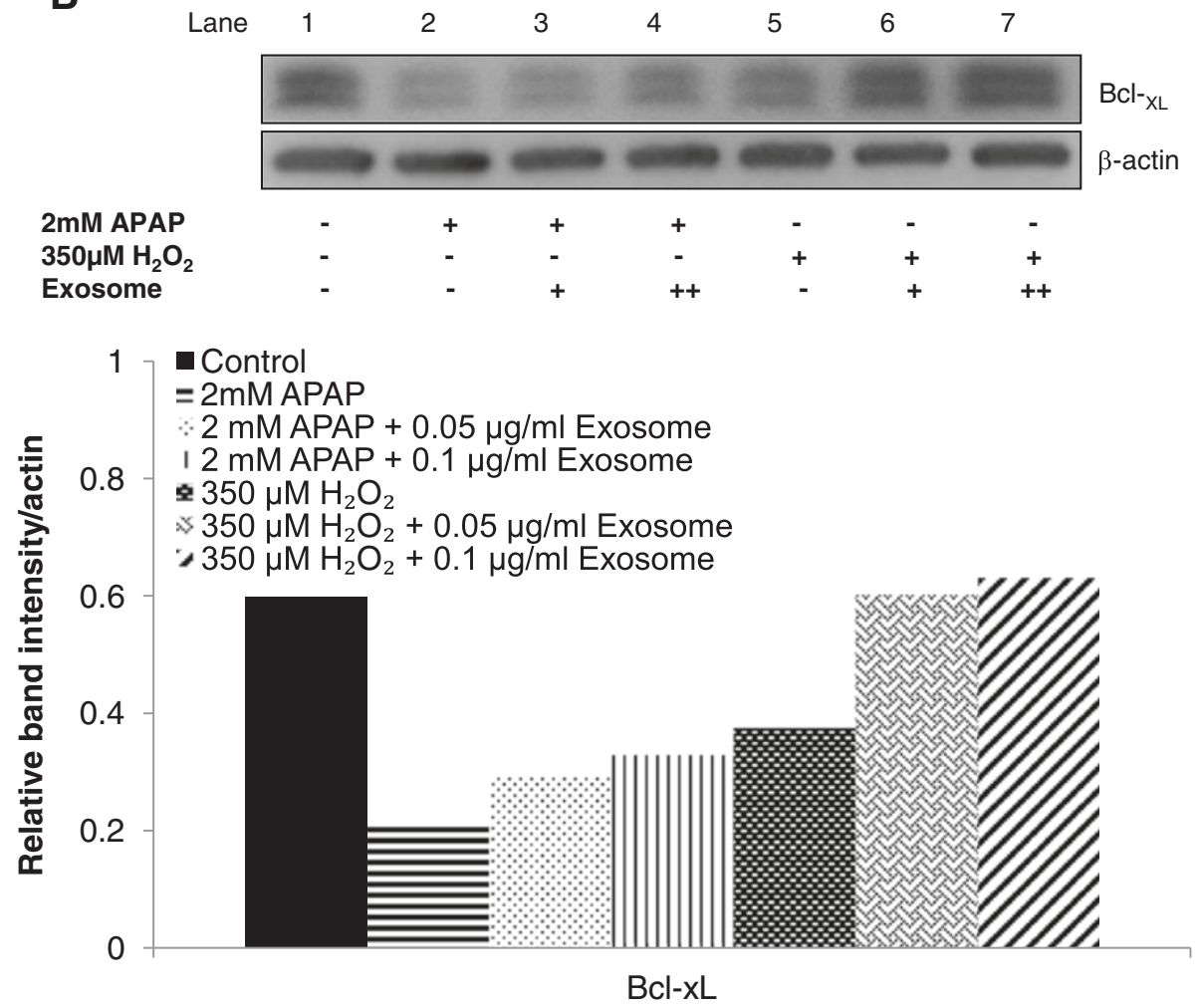

Figure 7 Effect of exosomes on antiapoptosis in APAP- or $\mathbf{H}_{2} \mathbf{O}_{2}$-induced injury in hepatocytes. (A) Caspase 3/7 was measured after 24-hour treatment of exosomes in APAP or $\mathrm{H}_{2} \mathrm{O}_{2}$ injury. (B) Expression of $\mathrm{BCl}_{-x L}$. was determined by immunoblotting after 24-hour treatment in the APAP- or $\mathrm{H}_{2} \mathrm{O}_{2}$-injury model. ${ }^{*} \mathrm{P}<0.05$ versus APAP or $\mathrm{H}_{2} \mathrm{O}_{2}$ non-exosomes treatment group. The relative densities of $\mathrm{BCl}-{ }_{-} \mathrm{L}$ bands were normalized to actin in the same samples.

of several stress/defense-related genes that are commonly involved in the oxidative pathway namely heme oxygenase-1 (HO-1), glutathione peroxidase 4 (Gpx4), glutathione reductase (GSR), and MnSOD were measured. In both injury models, only HO-1 mRNA expression was highly induced at the 24-hour time point of each toxicant treatment, whereas Gpx4, GSR, and MnSOD genes remained relatively unchanged, as compared with control. However, no significant difference appeared between the exosomesand non-exosomes-treated groups (Figure 8A,B).

\section{Discussion}

We hypothesized that the size-purified subset of exosomes derived from MSC-CM can play a role in mitigating 


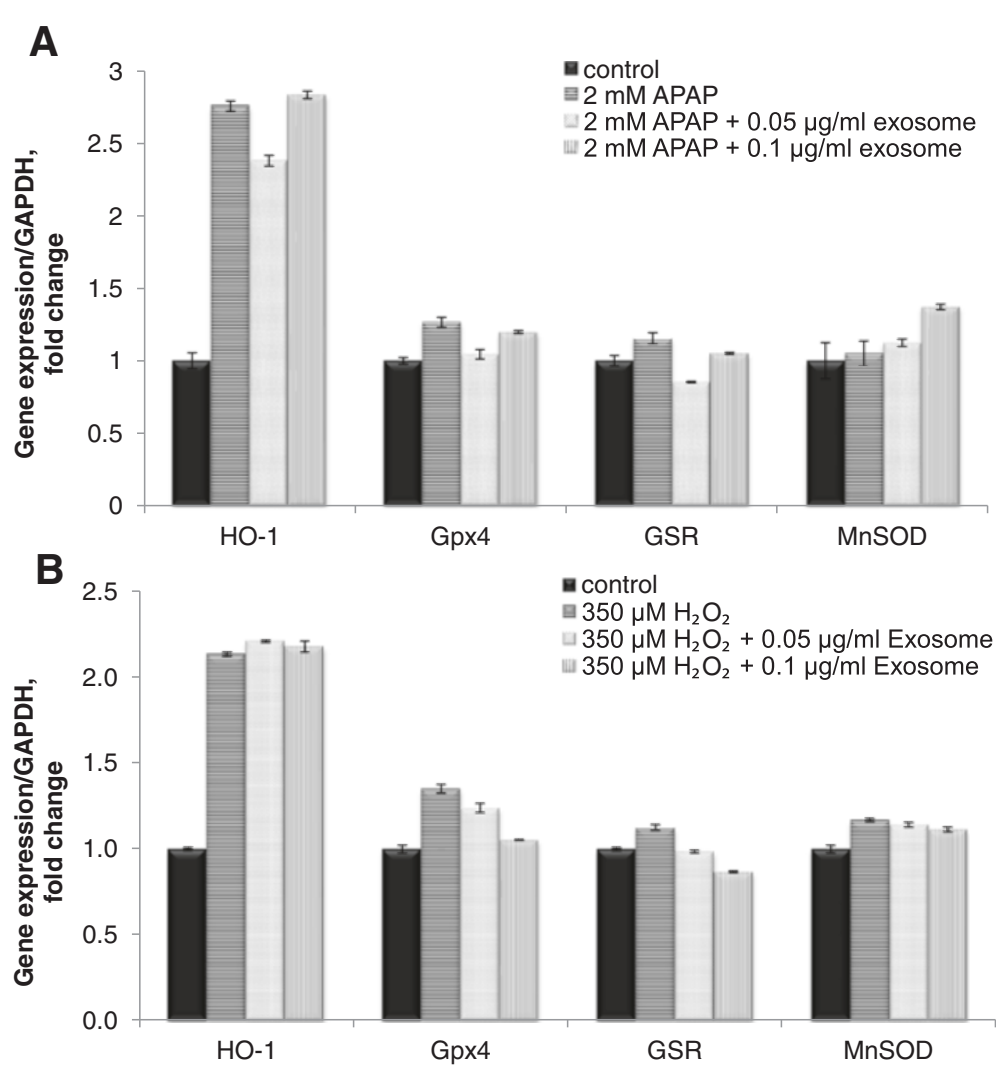

Figure 8 Effect of exosomes on antioxidation in APAP- or $\mathrm{H}_{2} \mathrm{O}_{2}$-induced injury in hepatocytes. Liver stress/defense-related genes expression in TAMH cells treated with or without exosomes concurrently in (A) $2 \mathrm{mM}$ APAP or (B) $350 \mu \mathrm{M} \mathrm{H}_{2} \mathrm{O}_{2}$ for 24 hours. All the expressions were determined by quantitative real-time PCR, normalized against GAPDH expression of the same sample and presented as fold-increase over the controls. Bars represent mean \pm SEM.

xenobiotic-induced liver injury. As a proof of concept, we explored such effect by using classic models of liver toxicity (that is, $\mathrm{CCl}_{4}$-induced hepatic injury in mouse). We further considered the selectivity and the mechanism of the anticipated protection by using in vitro models of well-defined mechanisms of toxicity: APAP and $\mathrm{H}_{2} \mathrm{O}_{2}$. Accordingly, our experiments demonstrated that the MSCderived exosomes accelerated in vivo liver regeneration in $\mathrm{CCl}_{4}$-injured mice. In addition, we found that exosomes consistently caused increased cell viability after the injury arising from both APAP- and $\mathrm{H}_{2} \mathrm{O}_{2}$.

In an in vivo study, $\mathrm{CCl}_{4}$ was used as a classic and wellestablished model of acute liver injury. The administration of MSC-derived exosomes was found to reverse $\mathrm{CCl}_{4}$ induced injury in mice with active proliferation of hepatocytes, most clearly indicated with the expression of PCNA, cyclin D1, and cyclin E. These proliferation effects were in line with the in vitro findings in which exosomes were able to sustain higher cell viability of hepatocytes after injuries cytotoxic doses of both APAP and $\mathrm{H}_{2} \mathrm{O}_{2}$. We qualified the regenerative potential of these exosomes by investigating the biochemical machinery behind the effect, beginning from the priming phase that triggers growtharrested injured cells to reenter cell cycle.

IL-6 [21] and TNF- $\alpha$ [22] are prominent priming factors in initiating liver regeneration on injury by committing cells to cell cycling. Yamada et al. [22] reported defective DNA synthesis in TNFR-I-deficient mice after partial hepatectomy, whereas IL-6 injection restored the liver regeneration. Besides these, iNOS has also been demonstrated to mediate the formation of nitric oxide (NO) $[23,24]$ and COX-2, which catalyzes the ratelimiting step in the synthesis of prostaglandins (PGs) that control the regenerative process. MIP-2 was also found to enhance hepatocytes proliferation through upregulating nuclear translocation of STAT-3 during the process of recovery from injury [25-27]. Our results demonstrated the increase in expressions of all these priming-phase factors after exosomes treatment alongside improved cell viability. Despite the use of a monoculture system comprising exclusively hepatocytes, we were able to pick up these cytokine perturbations, consistent with other similar liver cell-line studies reported in the literature $[28,29]$. 
TNF initiates liver regeneration by activating the NF$\mathrm{\kappa B}$ and IL-6-dependent pathway, which involves STAT3 transcription factor [30] in the $\mathrm{G}_{1}$ phase. In the current investigation, Western blot demonstrated that injured hepatocytes with exosomes treatment markedly increased the expression of NF- $\mathrm{kB}$ and STAT3 transcription factors. The IL-6/STAT3 pathway subsequently innervates cell-cycle progression from $G_{1}$ to $S$ phase, as shown in the upregulation of cyclin D1 and PCNA after exosomes treatment. In line with the priming factors and transcription factors, all these upregulated gene and protein expressions collectively support a restoration of overall cell viability, suggesting that the exosomes therapy likely mediates the liver repair from acute liver injury through induction of liver regeneration in the hepatocytes.

In the process of characterizing the mode of action of exosomes, we were aware of a possible differential response to the type of cellular injury invoked by the toxicants. Hence, two mechanistically distinct injury models were investigated. APAP is a well-studied hepatotoxicant that mediates the liver-injury pathway principally through generation of its reactive metabolite, $N$-acetyl- $p$-benzoquinoneimine (NAPQI) and subsequent binding to hepatic proteins [31], whereas $\mathrm{H}_{2} \mathrm{O}_{2}$ mediates liver injury solely through the oxidative-stress pathway. However, a common effect observed in both injuries is the manifestation of mitochondrial dysfunction, leading to apoptosis [32,33]. Because the exosomes demonstrated a protective or injury-repair effect in both models, albeit to a different extent, a possible effect in mitigating oxidative stress was investigated. Previously, STAT3 was also shown to regulate mitochondrial $\mathrm{Bcl}_{-\mathrm{xL}}$ and MnSOD expression in inhibiting caspase 3 during apoptosis $[18,20]$. Our results demonstrated that the $\mathrm{Bcl}_{-x \mathrm{~L}}$ expression increased with higher expression of STAT3 after the treatment of exosomes, whereas caspase $3 / 7$ expression was significantly decreased in the APAP-injury group treated with exosomes. This suggests that exosomes were able to alleviate some mitochondrial dysfunction as part of its plethora of protective mechanisms in the antiapoptosis pathway. However, exosomes did not demonstrate a role in regulating antioxidative genes, and hence did not mitigate injury via modulation of oxidative stress. These suggest that exosomes primarily assert antiapoptotic, proliferative, and regenerative hepatic responses to liver damage.

Follow-up work would be necessary to determine the hepatoprotective components within the exosomes. Exosomes have been shown to contain biologically active proteins, lipids, mRNA, and miRNA [34-36]. Lai et al. profiled a total of 857 proteins in the exosomes by using mass spectrometry and antibody array [37]. Here, few of the prominent proteins that are potential components involved in the liver-regeneration process were identified.
Among them, IL6ST/gp130, TNFRSF1A/TNFR1, and CXCL2/MIP-2 proteins were found to be associated with the priming factors during liver regeneration. IL6ST plays an important role in mediating the IL-6/STAT3 pathway, which initiates the hepatocytes protection [38-40]. Likewise, CXCL2/MIP-2 enhances hepatocytes proliferation through upregulating STAT-3 during the process of recovery from injury [25-27]. These proteinaceous contents could be released from the exosomes intrahepatically, triggering the higher expressions of IL- 6 , TNF- $\alpha$, and MIP-2 after treatment, as shown in our results.

Apart from the priming factors, HGF and hepatocyte growth factor receptor (HGFR) proteins, which are among the most potent stimulators of hepatocyte growth in liver regeneration $[41,42]$, can also be found in the exosomes. These proteins might be working synergistically with the priming factors in accelerating and promoting liver regeneration, leading to a restoration of homeostasis. However, it remains to be determined whether miRNAs or other mRNAs found in the exosomes may have any impact on the proliferation effect of the hepatocytes.

\section{Conclusion}

In conclusion, exosomes treatment demonstrated liver recovery after several toxicants-induced injuries. It is mediating this effect, likely through maintaining the liver homeostasis, that primarily includes inducing hepatocytes regeneration. This treatment may present a novel adjunctive therapy in drug-induced liver toxicity, in lieu of the limited availability of the conventional liver transplants. Its attractiveness also lies largely on its non-cell-based system, which reduces the risk of tissue incompatibility, while using an abundant and reproducible supply. This work supports further investigation to clarify the exact mechanism of action so that the intended therapeutic effect can be translated and optimized.

\footnotetext{
Abbreviations

ALT: Alanine aminotransferase; APAP: acetaminophen; AST: aspartate aminotransferase; BSA: bovine serum albumin; CCl4: carbon tetrachloride; COX-2: cyclooxygenase-2; DMEM/F12: Dulbecco modified Eagle medium/ Ham F12; DMSO: dimethylsulfoxide; FBS: fetal bovine serum; Gpx4: glutathione peroxidase 4; GSR: glutathione reductase; $\mathrm{H} \& \mathrm{E}$ : hematoxylin and eosin; $\mathrm{H}_{2} \mathrm{O}_{2}$ : hydrogen peroxide; $\mathrm{HGF}$ : hepatocyte growth factor; HGFR: hepatocyte growth factor receptor; HO-1: heme oxygenase-1; HPLC: high-performance liquid chromatography; IL-6: interleukin 6; iNOS: inducible nitric oxide synthase; ip: intraperitoneal injection; is: intrasplenic injection; ITS: insulin, transferrin, selenium; MIP-2: macrophage inflammatory protein 2; MnSOD: manganese superoxide dismutase; MSC-CM: mesenchymal stem cell-conditioned medium; MTT: 3-(4,5-dimethylthiazol-2-yl)-2,5-diphenyltetrazolium bromide; NAPQI:

$\mathrm{N}$-acetyl-p-benzoquinoneimine; NO: nitric oxide; PBS: phosphate-buffered saline; PCNA: proliferating cell nuclear antigen; PG: prostaglandin;

PMSF: phenylmethanesulfonyl fluoride; qRT-PCR: quantitative real-time polymerase chain reaction; TFF: tangential flow filtration; TGF-a: transforming growth factor alpha; TNF-a: tumor necrosis factor alpha.
}

\section{Competing interests}

The authors declare that they have no competing interests. 


\section{Authors' contributions}

CYT performed all the in vivo and in vitro assays including the biochemical and mechanism studies, data analysis, and interpretation, and drafted the manuscript. WW performed early characterization of exosomes in cell cultures. RCL and SKL contributed the MSC-derived exosomes and provided substantial contributions to the exosomes conception and information. YYD made substantial contributions to the design and interpretation of an in vivo model. HKH is the principal investigator for the overall project and supervised CYT in all aspects of this work. All authors read and approved the final manuscript.

\section{Acknowledgements}

This work was supported by NMRC grant R-148-000-125-275 (HKH) and BMRC intramural research funds (SKL). The authors thank A/Prof Mei Lin Go for her mentorship and guidance.

\section{Author details}

'Department of Pharmacy, National University of Singapore, Block S4 18 Science Drive 4, Singapore 117543 , Singapore. ${ }^{2}$ Department of Gastroenterology, National University Hospital, 5 Lower Kent Ridge Road, Singapore 119074, Singapore. ${ }^{3}$ Institute of Medical Biology, Agency for Science Technology and Research, Singapore 138648, Singapore.

Received: 21 February 2014 Revised: 30 May 2014

Accepted: 2 June 2014 Published: 10 June 2014

\section{References}

1. Thorgeirsson SS: Hepatic stem cells in liver regeneration. FASEB J 1996, 10:1249-1256

2. Navarro VJ, Senior JR: Drug-related hepatotoxicity. N Engl J Med 2006, 354:731-739.

3. Daniels D, Grytdal S, Wasley A: Centers for Disease Control and Prevention: surveillance for acute viral hepatitis, United States, 2007. MMWR Surveill Summ 2009, 58:1-27.

4. Song L, Tuan RS: Transdifferentiation potential of human mesenchymal stem cells derived from bone marrow. FASEB J 2004, 18:980-982.

5. Le Blanc K, Pittenger M: Mesenchymal stem cells: progress toward promise. Cytotherapy 2005, 7:36-45.

6. Zagoura DS, Roubelakis MG, Bitsika V, Trohatou O, Pappa KI, Kapelouzou A, Antsaklis A, Anagnou NP: Therapeutic potential of a distinct population of human amniotic fluid mesenchymal stem cells and their secreted molecules in mice with acute hepatic failure. Gut 2012, 61:894-906.

7. Kanazawa H, Fujimoto Y, Teratani T, Iwasaki J, Kasahara N, Negishi K, Tsuruyama T, Uemoto S, Kobayashi E: Bone marrow-derived mesenchymal stem cells ameliorate hepatic ischemia reperfusion injury in a rat model. PLoS One 2011, 6:e19195.

8. Yan YM, Xu WR, Qian H, Si Y, Zhu W, Cao HL, Zhou HX, Mao F: Mesenchymal stem cells from human umbilical cords ameliorate mouse hepatic injury in vivo. Liver Int 2009, 29:356-365.

9. Sze SK, de Kleijn DP, Lai RC, Khia Way Tan E, Zhao H, Yeo KS, Low TY, Lian Q, Lee CN, Mitchell W, El Oakley RM, Lim SK: Elucidating the secretion proteome of human embryonic stem cell-derived mesenchymal stem cells. Mol Cell Proteomics 2007, 6:1680-1689.

10. Lai RC, Arslan F, Lee MM, Sze NS, Choo A, Chen TS, Salto-Tellez M, Timmers L, Lee CN, El Oakley RM, Pasterkamp G, de Kleijn DP, Lim SK: Exosome secreted by MSC reduces myocardial ischemia/reperfusion injury. Stem Cell Res 2010, 4:214-222.

11. Lai RC, Arslan F, Tan SS, Tan B, Choo A, Lee MM, Chen TS, Teh BJ, Eng JK, Sidik H, Tanavde V, Hwang WS, Lee CN, El Oakley RM, Pasterkamp G, de Kleijn DP, Tan KH, Lim SK: Derivation and characterization of human fetal MSCs: an alternative cell source for large-scale production of cardioprotective microparticles. J Mol Cell Cardiol 2010, 48:1215-1224.

12. Wu JC, Merlino G, Cveklova K, Mosinger B Jr, Fausto N: Autonomous growth in serum-free medium and production of hepatocellular carcinomas by differentiated hepatocyte lines that overexpress transforming growth factor alpha 1. Cancer Res 1994, 54:5964-5973.

13. Pfeifer AM, Cole KE, Smoot DT, Weston A, Groopman JD, Shields PG, Vignaud JM, Juillerat M, Lipsky MM, Trump BF: Simian virus 40 large tumor antigen-immortalized normal human liver epithelial cells express hepatocyte characteristics and metabolize chemical carcinogens. Proc Natl Acad Sci U S A 1993, 90:5123-5127.
14. Coe KJ, Jia Y, Ho HK, Rademacher P, Bammler TK, Beyer RP, Farin FM, Woodke L, Plymate SR, Fausto N, Nelson SD: Comparison of the cytotoxicity of the nitroaromatic drug flutamide to its cyano analogue in the hepatocyte cell line TAMH: evidence for complex I inhibition and mitochondrial dysfunction using toxicogenomic screening. Chem Res Toxicol 2007, 20:1277-1290.

15. Plumb JA, Milroy R, Kaye SB: Effects of the $\mathrm{pH}$ dependence of 3-(4,5dimethylthiazol-2-yl)-2,5-diphenyl-tetrazolium bromide-formazan absorption on chemosensitivity determined by a novel tetrazoliumbased assay. Cancer Res 1989, 49:4435-4440.

16. Reid AB, Kurten RC, McCullough SS, Brock RW, Hinson JA: Mechanisms of acetaminophen-induced hepatotoxicity: role of oxidative stress and mitochondrial permeability transition in freshly isolated mouse hepatocytes. J Pharmacol Exp Ther 2005, 312:509-516.

17. Kirillova I, Chaisson M, Fausto N: Tumor necrosis factor induces DNA replication in hepatic cells through nuclear factor kappaB activation. Cell Growth Differ 1999, 10:819-828.

18. Fukada T, Hibi M, Yamanaka Y, Takahashi-Tezuka M, Fujitani Y, Yamaguchi T, Nakajima K, Hirano T: Two signals are necessary for cell proliferation induced by a cytokine receptor gp130: involvement of STAT3 in anti-apoptosis. Immunity 1996, 5:449-460

19. Haga S, Terui K, Zhang HQ, Enosawa S, Ogawa W, Inoue H, Okuyama T, Takeda K, Akira S, Ogino T, Irani K, Ozaki M: Stat3 protects against Fas-induced liver injury by redox-dependent and -independent mechanisms. J Clin Invest 2003, 112:989-998.

20. Terui K, Enosawa S, Haga S, Zhang HQ, Kuroda H, Kouchi K, Matsunaga T, Yoshida $\mathrm{H}$, Engelhardt JF, Irani K, Ohnuma N, Ozaki M: Stat3 confers resistance against hypoxia/reoxygenation-induced oxidative injury in hepatocytes through upregulation of Mn-SOD. J Hepatol 2004, 41:957-965.

21. Clavien PA: IL-6, a key cytokine in liver regeneration. Hepatology 1997, 25:1294-1296

22. Yamada Y, Kirillova I, Peschon JJ, Fausto N: Initiation of liver growth by tumor necrosis factor: deficient liver regeneration in mice lacking type I tumor necrosis factor receptor. Proc Natl Acad Sci U S A 1997, 94:1441-1446.

23. Hortelano S, Dewez B, Genaro AM, Diaz-Guerra MJ, Bosca L: Nitric oxide is released in regenerating liver after partial hepatectomy. Hepatology 1995, 21:776-786.

24. Fausto N, Campbell JS, Riehle KJ: Liver regeneration. Hepatology 2006, 43:S45-S53.

25. Ren X, Carpenter A, Hogaboam C, Colletti L: Mitogenic properties of endogenous and pharmacological doses of macrophage inflammatory protein-2 after 70\% hepatectomy in the mouse. Am J Pathol 2003, 163:563-570.

26. Colletti LM, Green M, Burdick MD, Kunkel SL, Strieter RM: Proliferative effects of CXC chemokines in rat hepatocytes in vitro and in vivo. Shock 1998, 10:248-257.

27. Clarke CN, Kuboki S, Tevar A, Lentsch AB, Edwards M: CXC chemokines play a critical role in liver injury, recovery, and regeneration. Am J Surg 2009, 198:415-419.

28. Dong W, Simeonova PP, Gallucci R, Matheson J, Fannin R, Montuschi P, Flood L, Luster Ml: Cytokine expression in hepatocytes: role of oxidant stress. J Interferon Cytokine Res 1998, 18:629-638.

29. Rowell DL, Eckmann L, Dwinell MB, Carpenter SP, Raucy JL, Yang SK, Kagnoff MF: Human hepatocytes express an array of proinflammatory cytokines after agonist stimulation or bacterial invasion. Am J Physiol 1997, 273:G322-G332.

30. Gilgenkrantz $\mathrm{H}$, Collin de l'Hortet A: New insights into liver regeneration. Clin Res Hepatol Gastroenterol 2011, 35:623-629.

31. Cohen SD, Pumford NR, Khairallah EA, Boekelheide K, Pohl LR, Amouzadeh $H R$, Hinson JA: Selective protein covalent binding and target organ toxicity. Toxicol Appl Pharmacol 1997, 143:1-12.

32. Li JM, Zhou H, Cai Q, Xiao GX: Role of mitochondrial dysfunction in hydrogen peroxide-induced apoptosis of intestinal epithelial cells. World $J$ Gastroenterol 2003, 9:562-567.

33. Meyers LL, Beierschmitt WP, Khairallah EA, Cohen SD: Acetaminopheninduced inhibition of hepatic mitochondrial respiration in mice. Toxicol Appl Pharmacol 1988, 93:378-387.

34. Cocucci E, Racchetti G, Meldolesi J: Shedding microvesicles: artefacts no more. Trends Cell Biol 2009, 19:43-51.

35. Gyorgy B, Szabo TG, Pasztoi M, Pal Z, Misjak P, Aradi B, Laszlo V, Pallinger E, Pap E, Kittel A, Nagy G, Falus A, Buzás El: Membrane vesicles, current 
state-of-the-art: emerging role of extracellular vesicles. Cell Mol Life Sci 2011, 68:2667-2688.

36. Valadi H, Ekstrom K, Bossios A, Sjostrand M, Lee JJ, Lotvall JO: Exosomemediated transfer of mRNAs and microRNAs is a novel mechanism of genetic exchange between cells. Nat Cell Biol 2007, 9:654-659.

37. Lai RC, Tan SS, Teh BJ, Sze SK, Arslan F, de Kleijn DP, Choo A, Lim SK: Proteolytic potential of the MSC exosome proteome: implications for an exosome-mediated delivery of therapeutic proteasome. Int J Proteomics 2012, 2012:971907.

38. Klein C, Wustefeld T, Assmus U, Roskams T, Rose-John S, Muller M, Manns MP, Ernst M, Trautwein C: The IL-6-gp130-STAT3 pathway in hepatocytes triggers liver protection in T cell-mediated liver injury. J Clin Invest 2005, 115:860-869.

39. Dierssen U, Beraza N, Lutz HH, Liedtke C, Ernst M, Wasmuth HE, Trautwein C: Molecular dissection of gp130-dependent pathways in hepatocytes during liver regeneration. J Biol Chem 2008, 283:9886-9895.

40. Wuestefeld T, Klein C, Streetz KL, Betz U, Lauber J, Buer J, Manns MP, Muller W, Trautwein C: Interleukin-6/glycoprotein 130-dependent pathways are protective during liver regeneration. J Biol Chem 2003, 278:11281-11288.

41. Ishii T, Sato M, Sudo K, Suzuki M, Nakai H, Hishida T, Niwa T, Umezu K, Yuasa S: Hepatocyte growth factor stimulates liver regeneration and elevates blood protein level in normal and partially hepatectomized rats. J Biochem 1995, 117:1 105-1112.

42. Jiang WG, Hallett MB, Puntis MC: Hepatocyte growth factor/scatter factor liver regeneration and cancer metastasis. Br J Surg 1993, 80:1368-1373.

doi:10.1186/scrt465

Cite this article as: Tan et al:: Mesenchymal stem cell-derived exosomes promote hepatic regeneration in drug-induced liver injury models. Stem Cell Research \& Therapy 2014 5:76.

\section{Submit your next manuscript to BioMed Central and take full advantage of:}

- Convenient online submission

- Thorough peer review

- No space constraints or color figure charges

- Immediate publication on acceptance

- Inclusion in PubMed, CAS, Scopus and Google Scholar

- Research which is freely available for redistribution 